\title{
Strategi Peningkatan Kompetensi Dalam Menyiapkan Aparatur Sipil Negara di Era Revolusi Industri 4.0
}

\section{Strategy to Increase Competence in Preparing State Civil Apparatus in the Industrial Revolution Era 4.0}

\author{
Devvy Pramasti Wulandari ${ }^{1}$ \\ ${ }^{1}$ Program Magister Pengembangan Sumber Daya Manusia, Sekolah Pascasarjana, \\ Universitas Airlangga. \\ E-mail: devvypramesti52@gmail.com
}

\begin{abstract}
The era of digitalization in the administration of government must have quality apparatus resources, integrity and professionalism in providing public services for the community. In Indonesia, especially in Lamongan Regency, it is related to the problem of the low quality of apparatus resources and competency development which is being faced by the digitalization era. The purpose of this research is how the state civil apparatus in Lamongan Regency can be able to develop its competence to improve the quality of the state civil apparatus. This research method uses descriptive research methods. The results of this study indicate that in order to achieve quality apparatus resources, it can be done by forming a superior generation of state civil servants to move towards Smart ASN in 2024.
\end{abstract}

Keywords: Competency Development, Civil Servant, Education and Training

\begin{abstract}
Abstrak
Era digitalisasi dalam penyelenggaraan pemerintah harus mempunyai sumber daya aparatur yang berkualitas, berintegritas dan profesionalisme dalam memberikan pelayanan publik untuk masyarakat. Di Indonesia khususnya Kabupaten Lamongan terkait dengan permasalahan rendahnya kualitas sumber daya aparatur dan pengembangan kompetensi yang sedang dihadapkan oleh era digitalisasi. Tujuan dari penelitian ini agar bagaimana aparatur sipil negara di Kabupaten Lamongan dapat mampu mengembangkan kompetensi nya untuk meningkatkan kualitas dalam diri aparatur sipil negara. Metode penelitian ini menggunakan metode penelitian deskriptif. Hasil penelitian ini menunjukkan bahwa untuk menuju sumber daya aparatur yang berkualitas maka dapat dilakukan dengan membentuk generasi aparatur sipil negara yang unggul untuk menuju Smart ASN di tahun 2024.
\end{abstract}

Kata kunci: Pengembangan Kompetensi, PNS, Diklat 


\section{Wulandari: " Strategi Peningkatan Kompetensi Dalam Menyiapkan Aparatur Sipil Negara ..."}

\section{Pendahuluan}

Perubahan dunia kini tengah memasuki era revolusi industri 4.0 atau revolusi industry dunia keempat dimana teknologi informasi telah menjadi basis dalam kehidupan manusia. Segala hal menjadi tanpa batas (borderless) dengan penggunaan daya komputasi dan data yang tidak terbatas (unlimited), karena dipengaruhi oleh perkembangan internet dan teknologi digital yang masif sebagai tulang punggung pergerakan dan konektivitas manusia dan mesin. Era ini juga akan mendisrupsi berbagai aktivitas manusia, masalah sumber daya manusia merupakan salah satu unsur penting dalam organisasi. Sumber daya manusia berperan menentukan arah dan kemajuan sebuah organisasi (Rohida, 2018a).

Di zaman sekarang ini dengan begitu pesatnya perkembangan teknologi yang semakin canggih sehingga setiap individu dituntut untuk dapat menggali segala sumber daya manusia yang dimiliki, untuk dapat menunjang kinerja kita sehingga akan sangat berpengaruh pada pelaksanaan tugas setiap hari. Bahkan sistem sarana dan prasarana dalam organisasi dapat terus berkembang dan terus disempurnakan seiring berjalannya waktu, sehingga suatu organisasi dapat berkembang sesuai dengan sumber daya manusia yang ada. Banyak para ahli berpendapat bahwa sumber daya manusia yang berkualitas sangat menentukan berhasil atau tidak suatu organisasi dengan kompetensi setiap pegawai yang ada. Untuk membentuk sosok aparatur seperti tersebut memang memerlukan waktu dan proses yang lama serta upaya yang tidak boleh berhenti.

Saat ini istilah kompetensi sudah menjadi hal yang lazim baik nasional maupun global, terutama menghadapi Revolusi 4.0. ukuran kinerja seseorang diukur dari hal-hal yang sifatnya konvensional seperti aspek keuangan, number of account, market share, efisiensi produksi, dan kecanggihan teknologi yang berujung pada produktivitas dan keberlangsungan usaha. Namun, banyak orang lupa bahwasanya kinerja organisasi tersebut di atas tidak akan terjadi apabila dikerjakan oleh orang-orang yang tidak memiliki passion, merasa kurang bahagia dan sejahtera, baik secara material maupun psikologikal, serta tidak kompeten. Orang yang kompeten artinya orang yang mampu memberikan kinerja terbaiknya pada jabatan atau fungsi yang diembannya (Silverius and Tripomo, 2021) 


\section{Jejaring Administrasi Publik, Vol. 13, No. 2, 2021, hal 101-120}

Revolusi industri 4.0 mengubah pandangan politik dan ekonomi dunia, dimana kemajuan industri menyebabkan hilangnya lapangan pekerjaan karena tergantikan oleh teknologi yang ada. Disisi lain, dengan adanya revolusi industri akan banyak kemudahan dan inovasi yang didapatkan dengan adanya dukungan teknologi digital (Rista, 2019). Hal ini dirasa penting karena Sumber Daya Manusia (SDM) selalu berperan aktif dan dominan dalam setiap kegiatan organisasi, antara lain SDM menjadi perencana, pelaku, dan penentu terwujudnya tujuan organisasi. Agar suatu organisasi mampu terus bertahan dan bersaing, dominasi teknologi saja tidak cukup jika tidak ditunjang oleh SDM yang unggul. Sumber Daya Manusia dalam suatu organisasi dapat diandalkan untuk menggerakkan sumber daya lainnya dalam mewujudkan tujuan bersama. Sumber Daya Manusia yang dibutuhkan organisasi adalah SDM yang sanggup menguasai teknologi dengan cepat, adaptif, responsif, terhadap perubahan-perubahan teknologi dan memiliki sikap melayani serta berintegritas tinggi. Rohida (2018) menyatakan bahwa diperlukan peningkatan keterampilan atau upskilling dan pembaruan keterampilan atau re-skilling terhadap SDM untuk benar-benar dapat berkompeten.

Seiring berkembangnya zaman, tuntuan akan produktivitas organisasi juga semakin tinggi. Apapun jenis organisasinya baik profit maupun non-profit secara otomatis harus mampu mengadapi komplekitas lingkungan. Demikian halnya organisasi pemerintah baik di pusat maupun di daerah, kinerjanya dituntut untuk selalu dapat melayani masyarakat beserta segala komplekitas kebutuhannya sebagai koteks lingkungannya. Kinerja organisasi dapat dikatakan sebagai akumulasi dari kinerja individu-individu yang bekerja sama di dalamnya. Begitu pula dengan kinerja organisasi pemerintahan yang tidak bisa lepas dari kinerja Aparatur Sipil Negara (ASN) sebagai individu-individu di dalamnya.

Berkaitan dengan kinerja ASN, beberapa penelitian menunjukkan bahwa terdapat suatu keterkaitan yang kuat antara kinerja pegawai dengan kompetensi pegawai. Seperti penelitian yang dilakukan (Emmyah, 2009) di Politeknik Negeri Ujung Pandang menunjukkan bahwa kompetensi pegawai memberikan pengaruh yang signifikan terhadap kinerja pegawai. Selain itu juga penelitian (Adiputra, 2011) di kantor Pelayanan Pajak Pratama Bandung Selatan yang menunjukkan bahwa terdapat hubungan yang kuat antara 


\section{Wulandari: " Strategi Peningkatan Kompetensi Dalam Menyiapkan Aparatur Sipil Negara ..."}

kompetensi dengan kinerja pegawai. Berdasarkan hal tersebut dapat diketahui bahwa kinerja ASN juga ditentukan oleh kompetensi ASN yang bersangkutan dengan tugas dan wewenangnya masing-masing.

Perlu diketahui bahwa kompetensi ASN di Indonesia masih mengalami permasalahan. Seperti yang diungkapkan mantan Menteri Pemberdayaan Aparatur Negara dan Reformasi Birokrasi, Azwar Abubakar pada 2012 silam bahwa Indonesia mengalami krisis ASN yang kompeten. Sebanyak 4,7 juta ASN di Indonesia, 95\% diantaranya tidak memiliki kompetansi di bidangnya (Hartawan, 2012). Hal yang senada juga muncul dari pakar Manajemen dan Kebijakan Publik Fisipol Universitas Gajah Mada dan Lembaga Administrasi Negara (LAN), Agus Dwiyanto. Permasalahan ASN di Indonesia ini bukan semata-mata pada kuantitas yang terlalu besar, melainkan lebih mandasar pada kualitas yakni kompetensi yang sangat minim (Prayogo, 2015).

Secara normatif keseriusan pemerintah terhadap penyelenggaraan Diklat ASN dapat dilihat sejak munculnya Peraturan Pemerintah Republik Indonesia Nomor 101 Tahun 2000 Tentang Pendidikan dan Pelatihan Jabatan Aparatur Sipil Negara. Secara kelembagaan, Pendidikan dan Pelatiahn (Diklat) ASN telah dibentuk Badan Kepegawaian Negara. Lembaga ini berfungsi sebagai pengendali yang bertanggung jawab atas pengembangan dan pengawasan standar kompetansi jabatan serta pengendalian pemanfaatan lulusan Diklat. Selain itu terdapat instansi pembina Diklat yakni, Lembaga Administrasi Negara (LAN) yang bertanggung jawab atas pengaturan, koordinasi, dan penyelenggaraan Diklat.

Kendati demikian tidak serta merta Diklat ASN yang sejauh ini dilakukan di Indonesia tidak menghadapi permasalahan. Seperti yang diketahui bahwa permasalahan yang terjadi pada Diklat ASN yakni mengenai ketidaksesuaian antara Diklat yang diselenggarakan dengan kebutuhannya. Mengingat masih adanya permasalahan yang menjangkiti penyelanggaraan Diklat ASN di Indonesia nampaknya perlu ada formula yang tepat untuk memperbaiki penyelanggaraan Diklat ASN. Terdapat suatu metode yang dapat dijadikan sebuah solusi atas permasalahan penyelanggaraan Diklat yang tidak sesuai dengan kebutuhannya. 
Betapa pentingnya SDM dalam menghadapi era industri 4.0, sehingga mendorong pemerintah daerah Kabupaten Lamongan bersegera menyiapkan SDM berkualitas dan memiliki bakat tinggi. Peningkatan daya saing SDM di Kabupaten Lamongan merupakan topik yang menarik untuk dikaji dan dibicarakan termasuk dalam rangka mempersiapkan diri menjalankan era industri 4.0. Penelitian ini perlu dilakukan dalam rangka strategi peningkatan kompetensi SDM di Kabupaten Lamongan khususnya para ASN Pemerintah Kabupaten Lamongan dalam menghadapi tantangan era disrupsi 4.0. Pembangunan SDM dalam menghadapi tantangan era disrupsi 4.0 bukan sekedar menjalankan program pelatihan dan pendidikan, namun membutuhkan strategi yang efektif, efisien, dan tepat sasaran. Berdasarkan hal tersebut, penelitian secara utuh, komprehensif, dan holistik mengenai strategi Pemerintah Kabupaten Lamongan melalui BKPSDM Kabupaten Lamongan sebagai solusi dalam menghadapi tantangan era disrupsi 4.0 merupakan hal krusial.

\section{Kerangka Konseptual}

\section{Revolusi Industri 4.0.}

Istilah I40 berasal dari istilah Jerman "Industrie 4.0" dan disebutkan di depan umum untuk pertama kalinya di "Pameran perdagangan Hannover" di 2011 di Jerman (Emanuele Gabriel Margherita and Braccini, 2021). Era revolusi industri 4.0 (era 4IR) ditandai dengan perpaduan teknologi yang mengaburkan batas antara bidang fisik, digital, dan biologis, yang secara kolektif disebut sebagai sistem siber fisik (cyber physical system). Selain itu, ditandai dengan munculnya terobosan di bidang robotika (robotics) (Prof. Dr. Eko Prasojo, 2021). Kecerdasan buatan mempunyai beberapa kelebihan dibandingkan kecerdasan alami, antara lain:

1. Lebih bersifat permanen.

Kecerdasan alami dapat berubah karena sifat manusia pelupa, sedangkan kecerdasan buatan tidak berubah selama sistem komputer tidak mengubahnya.

2. Lebih mudah diduplikasi dan disebarkan.

Mentransfer pengetahuan manusia membutuhkan proses yang sangat lama dan tidak akan pernah dapat diduplikasi dengan lengkap, sedangkan pengetahuan yang terletak 


\section{Wulandari: " Strategi Peningkatan Kompetensi Dalam Menyiapkan Aparatur Sipil Negara ..."}

pada suatu sistem komputer dapat disalin dan dipindahkan dengan mudah ke komputer yang lain.

3. Lebih murah.

Menyediakan layanan komputer akan lebih mudah dan murah dibandingkan mendatangkan seseorang untuk mengerjakan sejumlah pekerjaan dalam jangka waktu yang sangat lama.

4. Bersifat konsisten dan teliti.

Kecerdasan buatan merupakan bagian dari teknologi komputer, sedangkan kecerdasan alami senantiasa berubah-ubah.

5. Dapat didokumentasi.

Kecerdasan buatan dapat dengan mudah didokumentasi dengan cara melacak setiap aktivitas dari sistem tersebut, sedangkan kecerdasan alami sangat sulit untuk direproduksi.

6. Cara kerja lebih cepat.

Komputer dapat mengerjakan beberapa task lebih baik dan cepat daripada manusia (Hartati, 2020)

Tidak bisa dihindari dan ditunda lagi, Indonesia harus melompat menuju pemerintahan berbasis digital. Perkembangan digitalisasi di sektor swasta dan juga di sektor publik di beberapa negara sudah sangat pesat dan terhubung dengan tuntutan Revolusi Industri 4.0. Hal tersebut melahirkan Governance 4.0 yaitu kondisi birokrasi yang ditandai dengan kecepatan dan konvergensi dalam semua urusan, baik dalam pemerintahan, pembangunan, maupun dalam pelayanan publik.

Pada sisi lain, karakteristik birokrasi Indonesia saat ini pada dasarnya masih berada pada level Governance 1.0 yang ditandai dengan orientasi politik yang masih tinggi, tumpang tindih berbagai program dan kegiatan antar instansi, dan berbagai proses bisnis yang manual dan terfragmentasi. Perkembangan konvergensi teknologi saat ini memberikan kesempatan yang besar bagi Indonesia untuk melompat menuju Governance 4.0. 


\section{Jejaring Administrasi Publik, Vol. 13, No. 2, 2021, hal 101-120}

\section{Kompetensi}

Istilah "Kompetensi" dalam bahasa Inggris disebut "Competencies" atau "Competence". Kamus Inggris-Indonesia mengartikan Competence sebagai suatu kemampuan atau kecakapan (Wojowasito dan Poerwadarminta, 1980). Dalam perkembangan selanjutnya istilah kompetensi ini mulai banyak dipakai orang dalam berbagai penggunaan dengan persepsi yang berbeda-beda, antara lain adalah penggunaan pada bidang manajemen sumber daya manusia. Spencer and spencer (dalam Sudarmanto, 2009) mengatakan, kompetensi merupakan karakteristik dasar perilaku individu yang berhubungan dengan kriteria acuan efektif dan atau kinerja unggul didalam pekerjaan atau situasi. Dengan kata lain, kompetensi merupakan landasan dasar karakteristik orang dan mengidentifikasikan cara berperilaku atau berpikir, menyamakan situasi, dan mendukung untuk periode waktu cukup lama. Kompetensi adalah sesuatu yang memiliki pengetahuan, keterampilan, dan kemampuan untuk menjadi efektif dalam bidang tertentu atau telah mencapai tingkat penguasaan (Ramon, 2013).Brian (dalam Sudarmanto, 2009) mendefinisikan kompetensi adalah pengetahuan, keahlian, kemampuan, atau karakteristik pribadi individu yang mempengaruhi secara langsung kinerja pekerjaan.

Kompetensi berasal dari kata "competency" merupakan kata benda yang menurut Powell (1997) diartikan sebagai 1) kecakapan, kemampuan, kompetensi; dan 2) wewenang. Kata sifat dari competence adalah competent yang berarti cakap, mampu, dan tangkas. Pengertian kompetensi ini pada prinsipnya sama dengan pengertian kompetensi menurut Stephen (2007) bahwa kompetensi adalah "kemampuan (ability) atau kapasitas seseorang untuk mengerjakan berbagai tugas dalam suatu pekerjaan, dimana kemampuan ini ditentukan oleh 2 (dua) faktor yaitu kemampuan intelektual dan kemampuan fisik.

Pengertian kompetensi sebagai kecakapan atau kemampuan juga dikemukakan oleh Roe (2001) sebagai berikut;Competence is defined as the ability to adequately perform a task, duty or role. Competence integrates knowledge, skills, personal values and attitudes. Competence builds on knowledge and skills and is acquired through work experience and learning by doing“Kompetensi dapat digambarkan sebagai 


\section{Wulandari: " Strategi Peningkatan Kompetensi Dalam Menyiapkan Aparatur Sipil Negara ..."}

kemampuan untuk melaksanakan satu tugas, peran atau tugas, kemampuan mengintegrasikan pengetahuan, ketrampilan-ketrampilan, sikap-sikap dan nilai-nilai pribadi, dan kemampuan untuk membangun pengetahuan dan keterampilan yang didasarkan pada pengalaman dan pembelajaran yang dilakukan.

Armstrong, M. and Baron, (2004) mengartikan kompetensi adalah apa yang orang bawa pada suatu pekerjaan dalam bentuk tipe dan tingkat-tingkat perilaku yang berbedabeda. Murphy (dalam Sedarmayanti., 2009) mendefinisikan kompetensi adalah bakat dan keahlian individu apapun yang dapat dibuktikan, dapat dihubungkan dengan kinerja yang efektif dan baik sekali. Rendahnya kinerja yang masih memerlukan perbaikan tersebut diasumsikan karena adanya beberapa faktor-faktor yang dapat memperbaiki kinerja karyawan, antara lain : keinginan, pengetahuan dan keterampilan, iklim, dukungan dan penghargaan, kompetensi, sikap etika kerja, tingkat penghasilan, dan tingkat pendidikan. Dari setiap faktor yang mempengaruhi kinerja pegawai, terdapat masalahmasalah yang cukup penting untuk disikapi antara lain: kurangnya kemampuan dan keterampilan pegawai yang masih memerlukan perbaikan dan pelatihan, pemberian motivasi dan dukungan yang kurang/rendah dari pimpinan, kurangnya perhatian pimpinan dalam memperhatikan suasana kekeluargaan, keharmonisan dan kesejahteraan pegawai, kurangnya keinginan dari pegawai untuk berubah agar menjadi lebih baik lagi, dan pimpinan kurang memberi penghargaan kepada pegawainya, pegawai sering menghabiskan waktu kerja dengan melakukan hal-hal yang tidak berhubungan dengan pekerjaannya, seperti: bermain game online, facebook, mendengarkan musik, dan sebagainya.

Pada dasarnya kemampuan individu untuk ingin lebih maju dan berkembang itu semua datangnya dari kemauan dan keinginan individu untuk banyak belajar, menggali semua potensi yang ada dalam diri sendiri dan yang terutama adalah pengembangan diri lewat peningkatan ilmu pengetahuan. Karena semua itu sangat menunjang dalam peningkatankinerja sebagai salah satu bentuk perwujudan yang dapat dilihat secara jelas kemampuan diri seseorang dalam melakukan suatu pekerjaan. Banyak ditemui pegawai negeri sipil, tidak mau lagi melanjutkan pendidikannya ke jenjang strata satu karena yang 
menjadi alasan mereka adalah faktor usia, tidak ada waktu luang untuk kuliah, kemampuan untuk belajar sudah tidak mampu lagi, dan juga tidak lama lagi memasuki masa persiapan pensiun. Sehingga dapat dilihat bahwa mereka tidak ingin berkembang demi peningkatan karir dan juga terutama dalam peningkatan kinerja. Aspek yang harus dilakukan untuk mewujudkan kompetensi, yaitu kerja keras dan keinginan yang besar untuk mau belajar dan terus belajar tanpa memikirkan hal-hal yang membatasi kita untuk mundur dan tidak ingin berkembang, sebab ilmu pengetahuan dan keterampilan yang dimiliki akan membawa kita pada sebuah kesuksesan.

Sebagai bentuk tanggung jawab pekerjaan dalam memajukan maka hendaknya kerajinan, loyalitas dan kreatifitas terus ditingkatkan dengan selalu berpikir positif serta menghilangkan semua kebiasaan buruk seperti: menunda-nunda pekerjaan, malas masuk kantor tetapi hendaknya memiliki suatu kemauan untuk terus berkembang. Jika kita sering menunda-nunda pekerjaan, malas masuk kantor dan tidak memiliki kemauan untuk berkembang maka akan sangat mempengaruhi kinerja kita. Oleh sebab itu dengan berpikir positif demi peningkatan kinerja maka dengan kerajinan, loyalitas, serta kreatifitas dapat meningkatkan kinerja.

\section{Pegawai Negeri Sipil/ Aparatur Sipil Negara}

Pegawai Negeri Sipil (Aparatur Sipil Negara), menurut Kamus Umum Bahasa Indonesia "Pegawai" berarti "orang yang bekerja pada pemerintahan (perusahaan dan sebagainya)" sedangkan "Negeri” berarti Negara atau pemerintahan. Jadi Pegawai Negeri Sipil adalah orang yang bekerja pada pemerintahan atau Negara (Hartini, 2008). Dalam pengetahuan hukum kepegawaian ada beberapa pendapat yang perlu dikemukakan mengenai apa sebenarnya pegawai negeri. Logemann menggunakan kriteria yang bersifat materiil yakni hubungan antara Negara dengan Pegawai Negeri tersebut. Logemann menyatakan bahwa Pegawai Negeri adalah tiap pejabat yang mempunyai hubungan dinas dengan Negara. Sedangkan pengertian pegawai negeri menurut Mahfud M.D. dalam buku Hukum Kepegawaian, terbagi dalam dua bagian yaitu: 


\section{Wulandari: " Strategi Peningkatan Kompetensi Dalam Menyiapkan Aparatur Sipil Negara ..."}

\section{Pengertian Stipulatif}

Pengertian yang bersifat stipulatif (penetapan tentang makna yang diberikan oleh Undang-Undang tentang Pegawai Negeri terdapat dalam Pasal 1 angka (1) dan Pasal 2 Undang-Undang No. 5 Tahun 2014 tentang Aparatur Sipil Negara. Pasal 1 angka 1 : Pegawai negeri adalah setiap warga negara Republik Indonesia yang telah memenuhi syarat yang ditentukan, diangkat oleh pejabat yang berwenang dan diserahi tugas dalam suatu jabatan negeri, atau diserahi tugas negara lainnya dan digaji berdasarkan peraturan perundang-undangan yang berlaku. Pasal 3 ayat (1) : Penyelenggaraan kebijakan dan Manajemen aparatur sipil Negara berdasarkan pada asas kepastian hukum, profesionalitas, proporsionalitas, keterpaduan, delegasi, netralitas, akuntabilitas, efektif dan efisien, keterbukaan, nondiskriminatif, pesatuan dan kesatuan, keadilan dan kesetaraan, dan kesejahteraan. Pengertian di atas berlaku dalam pelaksanaan semua peraturan-peraturan kepegawaian dan pada umumnya dalam pelaksanaan semua peraturan perundang-undangan.

\section{Pengertian Ekstensif}

Selain dari pengertian stipulatif ada beberapa golongan yang sebenarnya bukan Pegawai Negeri, menurut Undang-Undang Nomor 5 Tahun 2014, tetapi dalam hal tertentu dianggap sebagai dan diperlukan sama dengan Pegawai Negeri (Hadjon, 1994). Dalam Undang-Undang No 5 Tahun 2014 tentang Aparatur Sipil Negara, dijelaskan bahwa pegawai negeri adalah setiap warga negara Indonesia yang telah memenuhi syarat yang ditentukan, diangkat oleh pejabat yang berwenang dan diserahi tugas dalam suatu jabatan negeri, atau diserahi tugas negara lainnya, dan digaji berdasarkan peraturan perundang-undangan yang berlaku. pegawai negeri terdiri dari: a. Pegawai Negeri Sipil; b. Anggota Tentara Nasional Indonesia; dan c. Anggota Kepolisian Negara Repubik Indonesia. Pegawai negeri sipil sebagaimana yang dimaksud dalam penjelasan diatas terdiri dari: A. Pegawai Negeri Sipil Pusat adalah: 1. Pegawai Negeri Sipil yang gajinya dibebankan pada Anggaran Pendapatan dan Belanja Negara (APBN) dan bekerja pada Departemen, Lembaga Non Departemen, Kesekretariatan Lembaga tertinggi/Tinggi Negara, dan kepaniteraan pengadilan. 2. Pegawai Negeri Sipil Pusat yang bekerja 
pada Perusahaan jawatan 3. Pegawai Negeri Sipil Pusat yang diperbantukan atau dipekerjakan pada daerah otonom. 4. Pegawai Negeri Pusat yang berdasarkan suatu peraturan perundangundangan diperbantukan atau dipekerjakan pada badan lain, seperti perusahaan umum, yayasan, dan lain-lain. 5. Pegawai Negeri Sipil Pusat yang menyelenggarakan tugas negara lain, seperti hakim pada pengadilan negeri, pengadilan tinggi, dan lain-lain. Dari pengertian diatas, penulis menarik kesimpulan bahwa pegawai negeri sipil adalah setiap warga Negara Indonesia yang bekerja pada instansi/lembaga pemerintahan dan digaji dengan anggaran pemerintah berdasarkan Perundang-undangan yang berlaku. B. Pegawai Negeri Sipil Daerah adalah : Pegawai Negeri Sipil Derah adalah pegawai negeri sipil daerah provinsi/kabupaten/kota yang gajinya dibebankan pada Anggaran Pendapatan dan Belanja Daerah (APBD) dan bekerja pada pemerintah daerah, atau dipekerjakan diluar instansi induknya (Moekijat, 1991).

\section{Pendidikan dan Pelatihan}

Menurut Rasto (2003), mengemukakan bahwa pendidikan dan pelatihan memberikan bantuan kepada karyawan agar dapat meningkatkan kemampuan kerja dan menumbuhkan pengertian tentang status dirinya dan tujuan perusahaan. Perbedaan antara pendidikan dan pelatihan yang sering kita pahami yaitu pendidikan merupakan upaya untuk meningkatkan pengetahuan umum dan sikap pegawai dan lebih banyak menekankan pada teori. Sedangkan pelatihan merupakan kegiatan untuk meningkatkan kecakapan. Pelatihan lebih banyak menekankan pada kegiatan praktik.

Notoatmodjo (2003), mengemukakan bahwa pendidikan dan pelatihan adalah suatu proses yang akan menghasilkan suatu perubahan perilaku sasaran pendidikandan pelatihan. Secara konkret perubahan perilaku itu berbentuk peningkatankemampuan dari sasaran pendidikan dan pelatihan. Kemampuan ini mencakupkognitif, afektif, maupun psikomotor. Apabila dilihat dari pendekatan sistem, makaproses pendidikan dan pelatihan itu terdiri dari input (sasaran diklat) dan output (perubahan perilaku), dan faktor yang mempengaruhi proses tersebut. 


\section{Wulandari: " Strategi Peningkatan Kompetensi Dalam Menyiapkan Aparatur Sipil Negara ..."}

Menurut Simamora (1997), pelatihan adalah serangkaian aktivitas yang dirancang untuk meningkatkan keahlian-keahlian, pengetahuan, pengalaman, ataupun perubahan sikap seorang individu. Pelatihan merupakan penciptaan suatu lingkungan dimana para karyawan dapat memperoleh atau mempelajari sikap, kemampuan, keahlian, pengetahuan dan perilaku yang spesifik yang berkaitan dengan pekerjaan. Dengan demikian pelatihan sangat berkaitan dengan upaya mendapatkan keahlian, pengalaman dan pengetahuan tertentu yang dapat membatu trainee dalam melaksanakan pekerjaannya.

Pendidikan dan Pelatihan adalah unsur utama dalam mengembangkan kemampuan pegawai. Kegiatan pendidikan diberikan untuk meningkatkan pengetahuan yang akan meningkatkan kinerja pegawai. Desain pelatihan yang sangat kompleks diberikan untuk membantu pegawai dalam mempelajari keterampilan baru yang akan meningkatkan kinerja mereka. Pegawai yang terampil dan berkompetensi sesuai dengan tugas daan pekerjaannya akan mampu membantu organisasi mencapai tujuan dan sasarannya.

\section{Metode Penelitian}

Metode yang digunakan dalam peneliti ini adalah metode penelitian deskriptif dengan Analisa data kualitatif. Sebagaimana menurut Nazir (2005)memberikan definisi mengenai metode penelitian deskriptif yaitu, pencarian fakta dengan interprestasi yang tepat. Penelitian deskriptif mempelajari masalah-masalah dalam masyarakat, serta tata cara yang berlaku dalam masyarakat serta situasi-situasi tertentu, termasuk tentang hubungan, kegiatankegiatan, sikap-sikap, pandangan-pandangan, serta proses yang berlangsung dan pengaruhpengaruh dari suatu fenomena. Dengan demikian penelitian deskriptif ini dapat mampu memberikan gambaran yang jelas tentang BKPSDM Kabupaten Lamongan mampu menyiapkan ASN di era digital.

Lokasi penelitian adalah tempat dimana penelitian akan dilakukan. Peneliti melakukan penelitiannya khususnya di BKPSDM Kabupaten Lamongan, karena BKPSDM Kabupaten Lamongan merupakan subjek utama dalam penelitian untuk diteliti. Sebagai upaya memperoleh data guna menjawab rumusan masalah terdapat dua jenis sumber data yang digunakan untuk peneliti ini. Adapun data tersebut adalah sebagai berikut: 
Data primer dalah data yang diperoleh secara langsung melalui terjung lapang dan juga data yang diperoleh langsung dari sumbernya, diamati dan dicatat untuk pertama kalinya. Dalam penelitian ini, data primer diperoleh langsung dari lapangan baik berupa hasil observasi maupun yang berupa hasil wawancara tentang bagaimana upaya BKPSDM Kabupaten Lamongan mampu menyiapkan ASN di era digital.

Data sekunder merupakan data yang dikumpulkan diolah dan disajikan oleh pihak lain, yang biasanya dalam bentuk jurnal tentang pengembangan kompetensi PNS dan diklat tentang PNS. Dalam penelitian ini, data sekunder diperoleh dengan menggunakan dokumendokumen dan jurnal yaitu pada buku-buku ilmiah, pendapat-pendapat pakar dan literatur yang sesuai dengan tema penelitian. Data sekunder dalam penelitian ini meliputi surat-surat, Salinan peraturan perundang-undangan profil instansi dan lembaga terkait yang diperoleh melalui dokumentasi. Dalam menerapkan metode deskriptif diajukan pertanyaan-pertanyaan terbuka kepada sumber data yang diperoleh dalam bentuk teks atau gambar.

Data sekunder dalam penelitian ini meliputi surat-surat, Salinan peraturan perundangundangan profil instansi dan lembaga terkait yang diperoleh melalui dokumentasi. Dalam menerapkan metode deskriptif diajukan pertanyaan-pertanyaan terbuka kepada sumber data yang diperoleh dalam bentuk teks atau gambar. Maka cara mengumpulkan data yang digunakan adalah sebagai berikut: Teknik ini digunakan untuk mengamati objek penelitian secara langsung serta meninjau lokasi-lokasi yang menjadi objek penelitian, dalam teknik atau kegiatan pencatatan tentang berbagai hasil pengamatan, gejala-gejala ataupun gambaran-gambaran yang berkaitan erat dengan masalah yang diteliti. Melalui observasi diharapkan peneliti dapat memahami kondisi lapangan sehingga lebih mudah dalam melakukan kegiatan penelitian ini. Observasi dilaksanakan di BKPSDM Kabupaten Lamongan sebagai instansi pemerintah ditingkat daerah dalam melakukan penelitian lapangan di BKPSDM Kabupaten Lamongan. Teknik wawancara ini untuk mengetahui dan memperoleh keterangan data dengan melakukan tanya jawab kepada sejumlah narasumber yang akan diteliti guna menjawab permasalahan penelitian yang akan diangkat. Melalui teknik wawancara inilah peneliti menggali data, informasi, dan kerangka keterangan dari subyek penelitian. Teknik ini digunakan untuk mengumpulkan data-data tertulis, yang berupa 


\section{Wulandari: " Strategi Peningkatan Kompetensi Dalam Menyiapkan Aparatur Sipil Negara ..."}

dokumen-dokumen, arsip-arsip serta data-data tertulis lainnya yang berhubungan, serta mendukung penelitian ini. Dokumentasi juga sebagai sumber data yang dimanfaatkan untuk menguji bahkan menafisrkan. Penelitian ini dilaksanakan dilingkungan kerja Badan Kepegawaian Daerah BKPSDM Kabupaten Lamongan untuk melengkapi dokumendokumen atau berkas yang penting.

\section{Hasil dan Pembahasan}

Dalam upaya menyiapkan ASN di era digital saat ini, tentu hal tersebut bukanlah hal yang mudah terutama bagi BKPSDM Kabupaten Lamongan. Dalam melakukan hal tersebut tentukan akan terdapat tantangan-tantangan yang menjadi hambatan dalam sukses atau tidaknya upaya yang dilakukan. Untuk Kabupaten Lamongan sendiri, ada beberapa yang menjadi tantangan dan harus diselesaikan oleh BKPSDM adalah seperti tingkat pendidikan ASN masih ada yang rendah, adanya ASN yang tidak memiliki motivasi untuk mengembangkan dirinya, masih adanya ASN yang belum paham terhadap penerapan teknologi di lingkung pemerintahan, dan jumlah anggaran yang masih terbatas dalam upaya pengembangan ASN.

Dilihat dari tingkat pendidikan ASN yang rendah, berdasarkan data dari BKPSDM Kabupaten Lamongan, pada tahun 2020 untuk ASN yang berpendidikan SD sebanyak 113 orang, SMP sebanyak 253 orang, dan SMA sebanyak 765 orang. Dari jumlah tersebut, jumlah pegawai yang dalam tingkat pendidikan yang rendah banyak terdapat di Dinas Lingkungan Hidup Kabupaten Lamongan yaitu SD 98 orang, SMP 214 orang dan SMA 345 orang, yang mana sebagian besar bekerja sebagai pasukan kuning (kebersihan).

Terkait dengan banyaknya pendidikan ASN yang rendah di Dinas Lingkungan Hidup Kabupaten Lamongan yang sebagian besar bekerja sebagai pasukan kuning (kebersihan) ini tentu kebanyakan tidak memiliki motivasi dalam upaya mengembangkan diri mereka. Hal ini dikarenakan mereka hanya sebagai pembersih kebersihan. Selain itu pegawai negeri sipil yang sudah tua dan masih berada di golongan bawah juga terkadang sudah tidak lagi memiliki motivasi dan berinovasi dalam mengembangkan diri mereka. Selain kendala yang 
dihadapi terkait dengan rendahnya motivasi dalam mengembangkan diri, yaitu terbatasnya alokasi anggaran untuk membiayai pengembangan kompetensi tersebut.

\section{Pengembangan Kompetensi ASN di Kabupaten Lamongan}

Dalam upaya meningkatkan kualitas kinerja seorang aparatur sipil negara untuk memberikan pelayanan publik dalam memberikan pelayanan yang efektif dan efesien di era digital, maka perlu dilakukannya pengembangan dan peningkatan kompetensi terhadap diri ASN. Sehingga dengan hal tersebut ASN memiliki kompetensi yang baik sehingga akan menunjang kemampuannya dalam memberikan pelayanan. Memiliki kompetensi yang baik dalam bekerja di pemerintahan maka akan manciptakan kualitas pemerintahan yang baik pula.

Di BKPSDM Kabupaten Lamongan, pengembangan kompetensi sebagai upaya meningkatkan kualitas dari seorang ASN merupakan sebuah upaya yang terus-menerus dilakukan untuk mampu menciptakan tata kelola pemerintahan yang baik di Kabupaten Lamongan. Beberapa cara yang telah dilakukan oleh BKPSDM Kabupaten Lamongan dalam meningkatkan dan mengembangkan kompetensi terhadap ASN yang ada di Kabupaten Lamongan adalah :

\section{Diklat}

Diklat adalah suatu program yang dirancang untuk dapat meningkatkan pengetahuan, kemampuan dan pemahaman pekerja atau pegawai terhadap keseluruhan lingkungan kerjanya. Dalam diklat sendiri mencakup 2 aspek yaitu pendidikan dan pelatihan yang masing-masing memiliki makna yang berbeda namun memiliki tujuan yang sama yaitu untuk meningkatkan kompetensi seseorang dalam melakukan pekerjaannya. Dengan mengikuti diklat diharapkan akan memberikan rangsangan atau stimulus terhadap sumber daya manusia (SDM) dalam meningkatkan kecakapan dan keterampilan yang diperlukan dalam mencapai tujuan dari organisasinya. 


\section{Wulandari: " Strategi Peningkatan Kompetensi Dalam Menyiapkan Aparatur Sipil Negara ..."}

Di Kabupaten Lamongan, ada beberapa diklat yang dilakukan oleh BKPSDM Kabupaten Lamongan terhadap PNS yang ada di Kabupaten Lamongan dalam meningkatkan kompetensi para pegawai adalah sebagai berikut:

\section{Diklat Budaya Kerja}

Diklat budaya kerja yang di lakukan oleh pemerintah Kabupaten Lamongan adalah bentuk komitmen dari pemerintah dalam upaya membangun sumber daya manusia, proses kerja, hasil kerja yang lebih baik, dan pencapaian peningkatan kualitas yang lebih baik. Dalam hal ini budaya kerja merupakan sesuatu yang berkaitan erat dengan perilaku dalam menyelesaikan pekerjaan. Perilaku ini merupakan cerminan dari sikap kerja yang didasari oleh nilai-nilai dan norma-norma yang dimiliki oleh setiap individu.

\section{Diklat Penilaian Properti}

Diklat ini dilakukan dengan tujuan untuk meningkatkan pengetahuan dan wawasan ASN dalam melakukan penilaian terhadap properti atau aset negara.

\section{Bimtek Pengadaan Barang dan Jasa}

Bimtek ini dilakukan dengan tujuan untuk menambah wawasan dan pengetahuan tentang pengadaan barang dan jasa pemerintah. Dalam Perpres nomor 4 tahun 2015 tentang Pengadaan Barang dan Jasa di lingkungan instansi pemerintah, pengadaan barang dan jasa pemerintah adalah kegiatan untuk memperoleh barang dan jasa oleh SKPD yang dimulai dari perencanaan kebutuhan sampai di selesaikannya seluruh kegiatan untuk memperoleh barang dan jasa.

\section{Sosialisasi}

Dalam hal sosialisasi BKPSDM Kabupaten Lamongan mengumpulkan semua Perangkat Daerah yang ada di lingkup pemerintahan Kabupaten Lamongan. Dengan narasumber dari KEMENPAN-RB, BKD Provinsi Jawa Tengah, dalam membuka wawasan mengenai revolusi industri 4.0 untuk memberikan pengarahan kepada sumber daya manusia 
terkait dengan hal tersebut. Para pegawai diberikan gambaran mengenai perubahanperubahan yang akan terjadi di dalam lingkup pemerintahan terutama dalam pelayanan publik akibat adanya revolusi industri 4.0 ini. Yang mana para pegawai dituntut memberikan pelayanan secara efektif dan efisien dan harus mampu menyesuaikan diri dengan perkembangan tekonologi digitalisasi. Sehingga ketika seseorang pegawai tidak mampu beradaptasi dengan perubahan tersebut maka akan menjadi sebuah permasalahan dalam mewujudkan konsep reformasi birokrasi yang telah dicanangkan oleh pemerintah pusat. Karena salah satu indikator dalam reformasi birokrasi adalah adanya kualitas pegawai yang mumpuni dan tanggap terhadap perubahan dalam pelayanan publik.

\section{Kesimpulan}

Era digitalisasi merupakan sebuah tuntutan dan juga tantangan yang harus dihadapi terutama dalam penyelenggaraan pemerintahan. Dalam era tersebut penyelenggaraan pemerintah dituntut untuk efektif, efisien, dan transparan guna menciptakan sebuah pelayanan yang baik bagi masyarakat. Untuk menghadapi era tersebut, maka penyelenggara pemerintahan dalam hal ini ASN dituntut untuk memiliki kompetensi dan kemampuan sehingga mampu beradaptasi dengan kemajuan teknologi di era digital tersebut. Sehingga dalam hal ini BKPSDM Kabupaten Lamongan memiliki peran yang sangat sentral dalam upaya meningkatkan kualitas ASN yang ada di lingkup pemerintahan Kabupaten Lamongan. Karena, adanya kualitas ASN yang baik merupakan sebuah landasan dalam menuju smart ASN sebagaimana telah dicanangkan oleh pemerintah pusat.

Konsep Smart ASN dalam hal ini yaitu pegawai dipandang sebagai sebuah investasi untuk institusi, yang mana jika karyawan atau pegawai tersebut dikelola dengan perencanaan yang baik dan lebih profesional maka akan memberikan imbalan bagi institusi lebih efektif dan efesien. Tahap perencanaan tersebut artinya mulai dari proses pendaftaran yang telah terintegrasi dan online, serta dilanjutkan sampai pada proses seleksi juga harus terkomputerisasi dan terbuka yang pada hakikatnya akan bermuara pada ASN yang dihasilkan dari proses perekrutan tersebut memiliki kriteria Smart ASN yang berintegritas, berwawasan global, serta memahami teknologi informasi bahasa asing. 


\section{Wulandari: " Strategi Peningkatan Kompetensi Dalam Menyiapkan Aparatur Sipil}

Negara ..."

\section{Saran}

1. Salah satu tantangan yang dihadapi oleh BKPSDM Kabupaten Lamongan dalam upaya pengembangan kompetensi adalah adanya anggaran yang terbatas. Sehingga untuk memaksimalkan pelaksanaan pengembangan kompetensi maka pemerintah harus mampu memberikan anggaran yang cukup sehingga akan mampu menunjang pelaksanaan tersebut

2. Perlu adanya peningkatan sosialisasi secara terus-menerus yang dilakukan oleh BKPSDM terhadap para perangkat daerah sehingga dengan hal tersebut akan diketahui apa yang menjadi permasalahan dalam perangkat daerah tersebut.

\section{Daftar Pustaka}

Adiputra, P. (2011) 'Hubungan Kompetensi Dengan Kinerja Pemeriksa'.

Armstrong, M. and Baron, A. (2004) Managing Performance: Performance management in action. London: CIPD.

Dr. Silverius Y. Soeharso, P. and Ir. Tedjo Tripomo, M. T. (2021) Soft Competencies Industry 4.0: Strategi Menyiapkan SDM Unggul di Era Disrupsi. Lautan Pustaka. Available at: https://books.google.co.id/books?id=Nw0VEAAAQBAJ.

Emanuele Gabriel Margherita and Braccini, A. M. (2021) 'Managing industry 4.0 automation for fair ethical business development: A single case study', Technological Forecasting \& Social Change.

Emmyah (2009) 'Pengaruh kompetensi terhadap kinerja pegawai pada politeknik negeri ujung pandang'.

Hadjon, P. M. D. (1994) Pengantar Hukum Administrasi Indonesia. Yogyakarta: Gadjah Mada Pers.

Hartati, I. (2020) 'Strategi Pembangunan Sdm Kementerian Keuangan Republik Indonesia Dalam Menghadapi Tantangan Era Disrupsi 4.0', Jurnal BPPK: Badan Pendidikan dan Pelatihan Keuangan, 13(1), pp. 109-129. doi: 
10.48108/jurnalbppk.v13i1.493.

Hartawan, A. A. T. (2012) Indonesia Krisis PNS yang Kompeten, Tempo.co. Available at: https://nasional.tempo.co/read/387194/menteri-azwar-indonesia-krisis-pns-yangkompeten/full\&view=ok (Accessed: 5 October 2021).

Hartini, Sri, Tedi Sudrajat, S. K. (2008) Hukum Kepegawaian Di Indonesia. Jakarta: Sinar Grafika.

Moekijat (1991) Administrasi Kepegawaian Negara. Bandung: Mandar Maju.

Nazir, M. (2005) Metode Penelitian. Jakarta: Ghalia Indonesia.

Notoatmodjo, S. (2003) Pengembangan Sumberdaya Manusia. Jakarta: PT Rineka Cipta.

Powell, T. . (1997) 'Information Technology as Competitive Advantage: the Role of Human, Business, and TechnologyResources.', Strategic Management Journal, 18(5).

Prayogo, R. (2015) Pakar: permasalahan PNS adalah kompetensi, antaranews.com. Available at: https://www.antaranews.com/berita/494973/pakar-permasalahanpns-adalah-kompetensi.

Prof. Dr. Eko Prasojo, M. rer. publ. (2021) Membangun Birokrasi Digital, Harian Kompas. Available at: https://fia.ui.ac.id/membangun-birokrasi-digital/ (Accessed: 7 October 2021).

Ramón, D. K. (2013) 'Cultural Competency, Adaptation and Intelligence: NonGovernmental Organizations' Role in this Globalization Era', Journal of Social Research \& Policy, 4(1).

Rasto., S. dan (2003) Manajemen Perusahaan Suatu Pendekatan Operatif dan Sistem Informasi. Bandung: UPI.

Rista, D. (2019) 'Strategi pemerintah dalam menghadapi revolusi industri 4.0 : haki', pp. 18.

Roe, R. A. (2001) 'Trust Implications for Performance and Effectivene', European Journ, Vol 12 No.

Rohida, L. (2018a) 'Pengaruh Era Revolusi Industri 4.0 terhadap Kompetensi Sumber Daya Manusia', Jurnal Manajemen Bisnis Indonesia, Vol. 6, No.

Rohida, L. (2018b) 'Pengaruh Era Revolusi Industri 4 . 0 terhadap Kompetensi Sumber Daya 
Wulandari: " Strategi Peningkatan Kompetensi Dalam Menyiapkan Aparatur Sipil Negara ..."

Manusia', 6, pp. 114-136.

Sedarmayanti. (2009) Sumber Daya Manusia dan Produktivitas Kerja. Bandung: CV Mandar Maju.

Simamora, H. (1997) Manajemen Sumberdaya Manusia. Cetakan PE. STIE YPKN.

Stephen, R. (2007) Perilaku Organisasi, Jilid 1 \& 2, Alih Bahasa:Hadyana Pujaatmaka. Jakarta: Indeks Kelompok Gramedia.

Sudarmanto (2009) Kinerja dan Pengembangan Kompetensi SDM. Yogyakarta: Pustaka Pelajar.

Wojowasito dan Poerwadarminta, W. (1980) Kamus Umum Bahasa Indonesia. Bandung: Penerbit Balai Pustaka. 